European Journal of Pragmatism and American Philosophy

VII-2 | 2015

John Dewey's Lectures in Social and Political Philosophy (China)

\title{
What Does China Mean for Pragmatism?
}

A Philosophical Interpretation of Dewey's Sojourn in China (1919-1921)

Roberto Gronda

\section{CpenEdition}

\section{Journals}

Electronic version

URL: http://journals.openedition.org/ejpap/406

DOI: $10.4000 /$ ejpap.406

ISSN: 2036-4091

\section{Publisher}

Associazione Pragma

Electronic reference

Roberto Gronda, « What Does China Mean for Pragmatism? », European Journal of Pragmatism and American Philosophy [Online], VII-2 | 2015, Online since 23 December 2015, connection on 01 May 2019. URL : http://journals.openedition.org/ejpap/406 ; DOI : 10.4000/ejpap.406

This text was automatically generated on 1 May 2019.

\section{c) (i)}

Author retains copyright and grants the European Journal of Pragmatism and American Philosophy right of first publication with the work simultaneously licensed under a Creative Commons AttributionNonCommercial-NoDerivatives 4.0 International License. 


\title{
What Does China Mean for Pragmatism?
}

\author{
A Philosophical Interpretation of Dewey's Sojourn in China (1919-1921)
}

\author{
Roberto Gronda
}

\section{Twilight of Idols, Birth of New Ideas}

1 "I think of James now because the recent articles of John Dewey's on the war suggest a slackening in his thought for our guidance and stir, and the inadequacy of his pragmatism as a philosophy of life in this emergency" (Bourne 1917: 199). With these famous words Randolph Bourne - a pupil of Dewey at Columbia University - expressed his bitter disappointment with Dewey's endorsement of American intervention in the first World War. The violence of Bourne's words - "slackening in his [Dewey's] thought," "inadequacy" - reveals the violence of the shock caused by Dewey's sudden decision to side with the pro-war faction. Dewey was not simply a pacifist; he was widely perceived as one of the leading intellectuals of the pacifist movement. No surprise, therefore, that Dewey's endorsement had stricken many of his friends and readers like a blow to the face.

Bourne's charge was simple and direct: he argued that Dewey's philosophy was an inspiring philosophy "for a society at peace" since it relied on the belief that human beings' greatest desire is for happiness and prosperity (Bourne 1917: 201). In this context, Bourne remarked, Dewey was right in holding that the best method at our disposal to achieve those goals was the scientific mentality, which investigated the intelligent relations between means and ends. However, in a time of war where these favorable conditions were no longer available, where the "store of rationality" was gone, human beings had experience of an increasing development and growth of irrational forces. In these conditions, Bourne concluded, Dewey's pragmatism proved itself to be an unreliable tool for shedding light on the problems of men. ${ }^{1}$

In what follows I will try to assess whether Bourne's remarks may function as a reliable historiographical hypothesis which would make sense of Dewey's philosophical 
development. The period from 1916 to 1921 is the most enigmatic in Dewey's life, from many different points of view. It is not by chance, I think, that relatively few studies have been devoted to investigating the transformations undergone by his thought in this brief span of time; it is as if the traditional interpretative categories that we usually apply to Dewey's philosophy reveal themselves to be not completely reliable when we turn our attention to the war and immediately post-war years. The thesis that I will articulate in the present article is that Dewey became engaged in a long and tortuous process of revision of his own philosophical position - a process which started in 1915, immediately after the outbreak of the First World War, continued during the war years, and lasted until about 1921, when he eventually went back to the United States after a two-year stay in China. I will suggest that that was a period marked by a need to put his philosophical assumptions to the test of reality, to be concrete, to be as close as possible to the world and to its complexity.

Consequently, I will assume that Bourne's criticism was substantially correct: at the time in which America had to decide whether or not to enter the war, Dewey's philosophy was inadequate to account for what was going on, and it could not supply Americans with the intellectual tools needed to choose rationally among the various, possible courses of action. But this is one part of the story. It should be added, indeed, that contrary to what Bourne seemed to believe, Dewey was well aware that the war in which America was becoming involved posed serious problems to his philosophy. He clearly perceived that his conceptual apparatus was not rich enough to account for the complexity of the new forces that were set in motion by that event.

In other words, what Bourne did not realize when he wrote "The Twilight of Idols" was that, at that time, Dewey's philosophy had already undergone significant modifications. According to the reading presented here, during the war years Dewey became aware that his philosophy was not sensitive enough to the complexity of the activity of thinking, and struggled to shape new conceptual tools that could account for those aspects (the social conditioning of thought, the 'ideological' composition of social reality) that had not been adequately taken into consideration in his previous texts. The problem with which Dewey was concerned was that of understanding the plurality of functions performed by theories and ideas in social life. Indeed, the clarification of the manifold effects of theory on social reality was necessary to the formulation of a sound pragmatist social philosophy - a project which, as Frega has convincingly shown in his contribution to the present symposium, was the hinge on which Dewey's philosophical work in the years 1918-1923 turned. To realize how important and how difficult it was for Dewey to come to term with that problem, it is enough to read the first chapter of the Lectures in China. In that chapter, significantly entitled "The function of theory," Dewey wrote that the question of the practical effect of theory was "the first great question concerning social philosophy" (Dewey 2015: I.3). However, his approach to that question was far from being clear and consistent: apparently, he conflated the different functions performed by theories, thus blurring the distinction between the effects that theories brought about when used as tools to reconstruct a problematic situation and the effects that stemmed from the fact that social reality is 'ideal' through and through, human behavior being necessarily in the realm of ideas and theories. Such a confusion - which was probably due to the need to provide his audience with all the concepts required to understand his argument in a small amount of time - is evidence of the tensions that marked his thought in that period of his life. 
6 In the following pages I will highlight the most relevant stages of the process that led Dewey to develop his new, original 'theory of theory,' as preliminary to the formulation of his social philosophy. I will not deal explicitly with his Lectures in China, but I will provide some background knowledge that I hope will be useful to understanding that text's place and significance in the overall context of Dewey's thought. The reconstruction attempted in this article is articulated in three distinct moments, which correspond to three different problematic situations with which Dewey found himself confronted. In section 2, I will discuss Dewey's reaction to German militarism, and I will emphasize the philosophical importance of the widely-neglected book German Philosophy and Politics within the economy of his thought. In section 3, I will focus on Dewey's reflections on the problem of propaganda, in order to bring to light the logical conclusions that he drew from the experience of the effects of the First World War on American society. Finally, in section 4, I will analyze Dewey's writings on China, with a particular attention to the articles in which he described and explained the Chinese civilization to his American audience. I will suggest that these articles present us with an extremely interesting and original account of the nature of thinking activity, which unfortunately almost disappeared in Dewey's later thought. Such an account was grounded on the theoretical results that he had achieved in the previous years - actually, it would not have been possible without them - and was the direct outcome of an extraordinary experience of intercultural exchange. From such a perspective, I will argue that Dewey's confrontation with the Chinese situation represented the completion of a line of thought aimed at reaching what may be labeled - using a famous Gramscian expression - "the absolute secularisation and earthliness of thought" (Gramsci 1971: 465).

\section{Understanding Germany: Philosophies of Life and Cultural Relativism}

7 On October, 4th, 1914 the New York Times published an appeal to 'the civilized world' signed by about one hundred influential German artists and intellectuals. The manifesto was intended to protest against 'the lies and calumnies' that were thrown at their country by those whom they referred to as 'our enemies' - that is, the Allies led by British and French governments and presses. The appeal's signatories - who proudly proclaimed themselves 'heralds of truth' - dismissed the accusations of cruelty and illegitimate use of violence by the German army as well as any charge that Germany was responsible for the war, and argued that, for historical reasons, militarism was a distinctive feature of German culture.

8 Dewey was strongly impressed by the content of the manifesto. As is well known, his most elaborated answer to the issue of Germanism was outlined in German Philosophy and Politics, originally published in 1915 (and then significantly reprinted in 1942). In this extremely controversial little book, Dewey argued rather surprisingly that the origin of German militarism should be sought not in Nietzsche's philosophy of power - as many contemporary interpreters were inclined to do - but in Kant's thought with its distinction between phenomena and noumena. If one looked more closely to the German culture, Dewey remarked, one could not escape from the impression that "the chief mark of distinctively German civilization is its combination of self-conscious idealism with unsurpassed technical efficiency and organization in the varied fields of action": "[i]f this 
is not a realization in fact of what is found in Kant," Dewey concluded, "I am totally at loss for a name by which to characterize it" (MW 8: 151).

Dewey did not maintain that Germans consciously adhered to the philosophy of Kant, that each and every action they did, or every decision they take, was evaluated in the light of that system of thought. He was well aware that a reading of this sort would have implied an overestimation of the power of ideas to control and direct human behavior. More cautiously, he argued that "Kant detected and formulated the direction in which the German genius was moving," and that "[i]n bringing to an imaginative synthesis what might have remained an immense diversity of enterprises, Kantianism helped formulate a sense of a national mission and destiny" (MW 8: 152). Kantianism provided Germans with a "banner and a conscious creed" in whose terms they could harmonize their external acts and their internal feelings and desires in the most consistent way (MW 8: 152). "Outside of Germany," Dewey remarked, "the career of the German idealistic philosophy has been mainly professional and literary"; it was in countries like France, England and the United States that it had revealed its purely theoretical significance (MW 8: 199). In Germany it performed a broader function: it was a 'philosophy of life.'

As is well known, Dewey's provocative interpretation of German civilization and its relation with American culture has been widely discussed and criticized. It is not my intention to take a position on this issue since it is not necessary for my present purposes. My point is more modest. I would simply like to avoid throwing away the baby with the bath water: the undeniable defects and shortcomings of Dewey's historical reconstruction should not impede us from seeing the important theoretical achievements that made that very analysis possible. More clearly stated, the thesis that I want to defend is that it would have been impossible for Dewey to thematize the relation between philosophy and politics in the way in which the issue is presented in German Philosophy and Politics if he had relied strictly on the standpoint formulated in his previous works. According to this reading, the introduction of the notion of philosophy of life represented a remarkable moment of rupture and change in Dewey's philosophical development, which forced him to profoundly revise his conceptual apparatus.

11 First of all, the very idea of a philosophy of life was difficult to accommodate within a theoretical framework that conceived of theories as tools for solving problems. Dewey's standard account of ideas and theories - for instance, as formulated in the Studies in Logical Theory - emphasized almost exclusively their logical value. Dewey's view was that the distinction between suggestions and ideas emerges precisely from the need of distinguishing the pre-reflective material of mental life (what comes unreflectively to our mind) from that very material in a later stage of its development, when it happens to acquire logical significance and value as a consequence of its being tested and controlled (for a definition of suggestion see, for instance, MW 6: 207ff.). Ideas and theories are logical notions which refer to a particular set of tools that originate within the process of inquiry, and whose import depends on their capacity to meet the needs and demands of the problematic situation that they are supposed to reconstruct. Now, it is evident that the way in which Dewey described the function performed by Kantian philosophy in the German world could not be traced back to the logical function performed by theories and ideas in the context of an inquiry. In the latter case, the function of a theory is that of rationally reconstructing a problematic situation; in the former, it is that of providing a general pattern of action, thought, and feeling that controls and directs the behavior of a group of people by working on a pre-rational, emotional level. 
12 For similar reasons, the conflict between the various philosophies of life could not be explained by reducing it to the conflict arising between alternative philosophical theories about a certain subject-matter. Indeed, the two kinds of conflict are governed by two different logics. Dewey was well aware of their difference since he was a master of the dialectical treatment of philosophical questions, and in many of his pre-war writings especially those dealing with ethical theory - he had made a large use of that technique of analysis. In those texts, Dewey usually presented his own position as the synthesis of different, competing philosophical theories. First of all, he started with arguing that the traditional accounts were flawed; then he tried to locate the specific source of their disagreement; and finally, he showed that neither of the two theories adequately accounted for a given range of phenomena because each theory selected a single aspect of the explanandum as determinant of the others. In doing so, Dewey showed that the two alternative theories adopted the same reductionist approach which conceived of the organic whole - for instance, the ethical behavior - as a sort of mechanism made up of single, independent parts, some of which were more fundamental than the others. As Dewey wrote in his Ethics, "the various types of theory are not arbitrary personal devices and constructions, but arise because, in the complexity of the subject-matter, one element or another is especially emphasized, and the other elements arranged in different perspectives" (MW 5: 209). A more promising approach, therefore, was that which acknowledged that no part was subordinate to the other, but that all the different elements were equally important moments of a whole. In the light of this assumption, the conflict between different philosophical theories could be recomposed in a higher unity, that is, in a higher explanation that gave equal recognition to all the features of the subject-matter.

13 Now, such a re-composition and reconciliation - which is the goal of the philosophical discussions - could not be attained in the case of conflicting philosophies of life. Indeed, it would be meaningless to say that the conflict between German and American philosophy of life could be recomposed in a higher unity; in this case, there is no explanation that could properly account for what is objectively valid in the various philosophies of life. Again, the difference between the two types of conflict depends upon the difference of function performed by philosophical theories, on the one hand, and philosophy of life, on the other hand. While the former have a truth-value, the latter have only a representative-value; while the former pretend to be true, the latter aim at articulating in a satisfactory way - satisfactory for the people who hold a particular philosophy of life the direction in which a particular national genius is moving. Accordingly, while the success of a philosophical theory is a consequence of its capacity to make sense of a specific subject-matter, the success of a philosophy of life stems from its capacity to be representative of a particular point of view. In other words, while the logic that governs the conflict between philosophical theories is monistic, the logic that governs the conflict between philosophies of life is intrinsically pluralistic.

The notion of philosophy of life posed a serious challenge to Dewey's thought because it was a sort of 'borderline' concept which cut across many of the functional distinctions that he had so patiently drawn in his previous writings. What was particularly difficult for him to formulate was the immediacy of the connection between thought and overt activity. Dewey had always insisted on the fact that theories and ideas suspend overt activity, that they are logical elements insofar as they contribute to the deliberate reconstruction of a new experience. For him, the essence of a theory was to be intermediate and mediating. 
Philosophies of life do not operate in this way; rather, they influence action in an immediate, direct and unreflective way. As Dewey wrote, through education they get embodied not in "men's minds," but rather "in their permanent dispositions of action" (MW 8: 141). They somehow infiltrate into the "habits of imagination and behavior" of a people, thus becoming part of their intellectual endowment.

If one focuses on the way in which philosophies of life operate, it is apparent that the latter are more similar to suggestions than to logical ideas. However, they are different from suggestions since a) they are highly refined and complex; b) they are valid not only for a single individual, but for a community of people; c) they are general. The last point is particularly relevant. Philosophies of life are general in the sense of being the horizons which influence and somehow predetermine the plausibility that a people is driven to acknowledge to different suggestions. I take this to be the meaning of the following sentence: "in this way can we get a clue to those general ideas with which Germany characteristically prefers to connect the aspirations and convictions that animate its deeds" (MW 8: 147). Here it seems clear that Dewey had in mind something like a Weltanschauung, a general conception of life permeating the beliefs, desires, and aspirations of a people. The main difference between the concept of Weltanschauung and Dewey's notion of philosophy of life is that the latter insists much more than the former on the intrinsic connection between a theory and the material and political conditions of the situation in which it originates. For Dewey, a philosophy of life is never a private option, an existential choice, something that a person can freely and individually choose to believe. Here as everywhere else, Dewey was highly suspicious of what was merely private, merely individual. A philosophy of life is something which is capable of providing a synthesis that could formulate "a sense of a national mission and destiny" (MW 8: 152).

In German Philosophy and Politics Dewey never uses the word ideology; nonetheless, it does not seem inappropriate to say that what he was trying to understand and describe in that book was precisely the ideological function of theories. Indeed, to become a philosophy of life, a general system of thought must be acknowledged by a group of people as their "banner" and "conscious creed"; they have to recognize themselves in the values and ideals that that system of thought defend. As is evident, such an insistence on the ideological function of theories has strong relativistic consequences: the idea that a philosophy of life supplies a people with "a sense of a national mission and destiny" means that the cultural world in which a man is raised influences the way in which he justifies his own beliefs. Different people holding different philosophies of life are guided by different ideals, different values, different beliefs as well as different standards of justification. Different people live in the same world, obviously, but they do not speak the same language (MW 10: 218).

17 Dewey explored the relativistic import of his 'new philosophy' in the article "On Understanding The Mind of Germany" (1916). In that article, which was a sort of continuation of German Philosophy and Politics, he discussed at length the problem of the possibility of intercultural understanding. Dewey did not believe that the plurality of philosophies of life supported a relativistic account of social life. He did not provide any argument in favor of this view, but it is very likely that he thought that the relativistic position was a too abstract description of the dynamics of intercultural interaction. In order to show how the conflicts between different cultures actually originated and how they could be settled, or at least defused, he introduced a concept, that of national philosophies, which differs from the notion of philosophy of life only in that the former 
puts more emphasis on the intrinsic connection between a system of thought and the political community to which it refers. National philosophies, he wrote, are different ways of articulating on a symbolic level the content that history had made "familiar and congenial" to a people. "Each nation," he remarked, "expresses its justification through the ideas which its past history has made most intelligible to itself - in terms, that is, of its national philosophy" (MW 10: 218-9).

By relating national philosophies to national histories, Dewey managed to found a concrete and positive ground on which to assess the problem of cultural relativism. He argued that the differences between national philosophies stemmed from the differences between national histories, which, in their turn, were influenced and transformed by the actions undertaken under the guidance of the former. That meant that the intercultural difference was not a brute fact, but rather the result of a long process of differentiation, which became obnoxious only when, for strictly historical reasons, a people did not enter in almost any relation with the others. That was the case of the Germans, for instance, and that was the reason why English and Americans found the mind of Germans much more difficult to penetrate than that of the French. So, the problem of relativism was not that of confronting different and incommensurable worldviews, but that of providing the conditions for entering in contact and becoming acquainted with other national communities. In Dewey's hands, a metaphysical problem was translated into a concrete, empirically testable hypothesis that suggested concrete and empirical solutions. In doing so, the relativistic implications of the existence of a plurality of philosophies of life - a fact that the outbreak of the First World War had brought violently to the fore - were substantially defused, and the description of the historical situation was made consistent with his overall position. A problem was turned into a fact: the menace of cultural relativism was replaced by the acknowledgment that cultural pluralism was one of the fundamental factors that any social philosophy had to take into account.

We can draw some conclusions from what has been said so far. Our starting point has been the hypothesis that the First World War presented Dewey with some facts that were not easily accounted for in his traditional instrumentalist framework. One of these facts was the ideological function performed by general theories, and the harmful political and social consequences that they could bring about. In order to account for this aspect of contemporary societies, Dewey developed the notion of philosophy of life. This notion enabled him to highlight the complexity of social reality: he conceived of philosophies of life as elements of social life enhancing the richness and diversity of the interactions among social agents. At the same time, that very notion compelled Dewey to take into consideration the complexity of the ideal dimension of human behavior. The analysis of the role played by Kantianism in German world made him aware that general theories and systems of thought were not merely logical tools; they could perform also a different function, which we have called ideological. Dewey did not openly discuss this issue, but it is evident that the problem with which he was concerned was that of understanding the ideological articulation produced by philosophies of life: the fundamental thesis of German Philosophy and Politics was precisely that the success of a philosophy of life depends on its capacity to articulate the forces at work in a specific community. This doctrine was in continuity with his instrumentalist position, but it was not logically deducible from it. Indeed, it relied on concepts that were not available to Dewey when he wrote the Studies in Logical Theory, and which were deeply interwoven with the philosophical anthropology that he was struggling to formulate - significantly, the lectures on which Human Nature 
and Conduct (1922) is based were delivered just a couple of years later, in 1918. As we will see in the last section of this article, this broad conception of instrumentalism was the theoretical tool that allowed Dewey to deal with a puzzling feature of the Chinese civilization.

\section{Dewey at War. Thought, Emotion and the Power of the Irrational}

In the opening pages of German Philosophy and Politics Dewey raised the question of the general validity of thought: the point at stake was that of understanding which kind of practical consequences were brought about by philosophies of life, in the context of a more general inquiry devoted to clarifying "the nature of the influence of general ideas upon practical affairs" - which Dewey himself defined as "a troubled question" (MW 8: 139). The same problem was tackled at the beginning of the article "On Understanding The Mind of Germany" as well as in the first chapter of the Lectures in China. The insistence with which Dewey discussed that issue in his writings can be taken as clear evidence of the importance that he attached to it in that particular moment of his life. In all these texts, he moved from the observation that the development of physical and psychical sciences had made it more and more difficult to stick to the belief that reason actually controls action. We need to believe that we are "lords" of our "intellectual structures," that we are creators of our conceptual structures, he argued, but unfortunately psychologists tell us that there are "vital instincts, obscure inclinations, imperative preferences" which are "at work below the surface of consciousness" and shape our "systems of belief" (MW 10: 216). Similarly, the development of physical sciences has brought about a lack of confidence in the power of reason and thought: a malicious interpretation of the results of physical sciences promotes the reduction of mind to a "bare spectator of a machine-like nature." Finally, the same conclusion has been reached by the theorists of evolution, who "regard intelligence as a deposit from history, not as a force in its making" (MW 8: 139).

21 All these episodes of distrust in reason are part of a much broader scenario which is essentially coincident with the history of modernity. ${ }^{2}$ As Dewey lucidly noted, modernity is prima facie paradoxical: in previous stages of civilization, when men had "least control over nature and their own affairs," they were nonetheless pretty confident in "the efficacy of thought" (MW 8: 139). On the contrary, in modern times scientific and technological discoveries have made available a huge number of tools and techniques which allow human beings to predict and control natural and social changes with a high degree of reliability. However, the enhancement of predictive and controlling power has gone hand in hand with an increasing perplexity about the force and efficacy of thought. Dewey formulated the paradox in this way: "Yet just in the degree in which men, by means of inventions and political arrangements, have found ways of making their thoughts effective, they have come to question whether any thinking is efficacious" (MW 8: 139). The fate of modernity is that of calling into question that very force that has generated it - the force of thought.

Dewey did not believe that what I have called 'the paradox of modernity' was genuine. In the end, he wrote, "like the rest of us," those who question the capacity of thought to direct and control natural and social events "are human, and infected with a belief that 
ideas, even highly abstract theories, are of efficacy in the conduct of human affairs" (MW 8: 140). But he argued that the lack of confidence in the force of thought which lay behind that paradox was a sign of something different and more profound, which had to do not with the metaphysical constitution of reality, but with the logical conditions of thought. In his early writing, Dewey had stressed that thinking is a fallible activity, grounded in no metaphysical or ontological warrant. The distinction that he had drawn between a constructive and a reconstructive conception of thought was precisely intended to emphasize the contingent and tentative character of every act of thought against those views that tended toward an absolutization of reason. Dewey's target were the upholders of Anglo-American idealism, a tradition of thought to which he himself had been strongly sympathetic: the distinction between thought as constructive and thought as reconstructive paved the way for the wholesale rejection of Absolute idealism with which Dewey inaugurated a new course of his thought.

During the war years Dewey came to realize not simply the fallibility of thought, but also its fragility. It is difficult to overestimate the importance of his increased awareness of the limits that beset the activity of thinking. In his early writings Dewey's main concern was to provide a sound criticism of the view that, in order to account for the meaningfulness of immediate experience, it is necessary to postulate a constitutive and unconscious activity of an Absolute mind of which the reflective and controlled activity of a finite mind is only a pale and powerless imitation. The problem now became that of arguing for the very possibility of thought. In the first case, the idea of the fallibility of thought was a means to save thought from the risk of its annihilation. In the second case, the feeling of the fragility of thought was the very problem stated in its simplest and clearest terms.

It would not be difficult to show how relevant the idea of 'limits of thought' was for Dewey's philosophy. However, to offer a detailed reconstruction of this notion exceeds the scope of the present paper. I will therefore use it as an unproblematic and wellgrounded concept, postponing its clarification and justification to a future article. With 'limits of thought' I mean to highlight two fundamental assumptions of Dewey's logical instrumentalism: on the one hand, the idea that the act of thinking originates from a problematic situation which sets the conditions for its valid application as a factor acting to solve the problem; on the other hand, the thesis that the scope of the act of thinking is restricted to the specific situation at stake.

These two assumptions were firstly formulated with clarity in the Studies in Logical Theory. My thesis is that, as a consequence of his experience of the effects of the war on the American society, Dewey subjected the idea of limits of thought to a substantial revision. In many of the texts that he wrote during that period, Dewey pointed out that thought could be limited in another additional way. He realized that the activity of thinking can be limited by particularly hostile social conditions which hamper the use of intelligence and experimentation.

In the article "Conscription of Thought" Dewey lucidly explained what he felt was the most threatening aspect of the state of war in which America was involved. Surprisingly enough, he stated that he was not particularly worried about the widely spread tendency to limit the liberty of thought and speech: the latter had been so severely menaced in the past that there was no sound reason to doubt that it could survive this new attack. In his eyes, much more harmful were those attacks that acted obliquely. Conscription of thought was an instance of the latter type in its most clearly marked form. In times of war, Dewey remarked, a people looked for social cohesion and unity, and rewarded them 
over and above any other thing. Consequently, any opinion perceived as a threat to social unity was banned. This happened even though history had shown the complete "inefficacy of the conscription of mind as a means of promoting social solidarity." From the point of view of its efficacy, indeed, conscription of thought was a self-defeating strategy. Much better would have been to encourage public discussion, because through the latter "unpopular ideas [...] burn themselves out or die of inanition," while the "direct suppression of thought" usually increases "the vitality of obnoxious beliefs" (MW 10: 277). The problem with the social dangerousness of conscription of thought lied therefore not in its intended consequences, but in the indirect and uncontrolled ones. Conscription of mind was socially and politically dangerous since it ended by undermining freedom of thought and speech by promoting absence of reflection and "apathy of intelligence" (MW 10: 279).

What Dewey had in mind was a sort of 'transcendental' criticism. His argument was that rather than being concerned with the various, 'positive' attempts to limit the activity of thought, one should be alert to those forces that aimed to transform the structure of the society, and, in doing so, posed a serious threat to the very conditions of possibility of thinking. According to Dewey, such forces were actually at work in American society. The means through which they were trying to bring about these social transformations was propaganda.

Dewey was concerned about the damages caused by propaganda. The events that took place in America during the war years made him aware that the negative effects of propaganda concerned society as a whole, and not simply one of its factions. Indeed, contrary to what was commonly believed, the real victims of propaganda were less those whose opinions were subjected to censorship than the censors and those who symphatized with them. While the former were prompted by the attack they continuously received to discuss and defend their own views, the latter tended to rest satisfied with the beliefs that were accepted and sanctioned by Government and by the silent majority of the population. Their answer to the challenges presented by different opinions was to get rid of them: by calling them seditious and threatening, they defused the situation of intellectual confrontation, and continued to follow obediently and unreflectively the path of tradition.

Dewey was deeply impressed by the fact that the vast majority of the American society was living in a condition of "hypersensitiveness of nerves," as a consequence of which the recourse to controlled thinking activity as a force to reconstruct problems was for them no more a real possibility (MW 10: 276). "Emotional perturbations," he wrote, "are so deep and general in war that any one who keeps himself outside can behold the suborning of intelligence in progress": the outcome of those perturbations was the reinforcement of "native partisanship of thought and belief," and a growing aversion towards "[i]mpartiality and detachment of mind" (MW 10: 216). By observing the dramatic changes in America, Dewey realized that emotional stir had taken the place of reflective and controlled reasoning. A people longing for a strong sense of national identity did not want to have the possibility to choose among different, competitive, and equally possible courses of activity. That plenty of opportunities was perceived as disturbing and distressing. Rather, Americans wanted to have a clear set of beliefs to hold, in the conviction that social and political unity could be attained only by outlawing different opinions. In times of war, emotion became therefore intelligence's greatest enemy: "[f]or an emotion which sweeps all before it, so undivided as to leave room but for 
one kind of thinking and one form of belief, affords a sweetly complete sense of certainty" (MW 10: 216).

It is important not to misunderstand the import of Dewey's remarks on propaganda. In his eyes, to acknowledge that a society becomes inhospitable to differences of opinions and to free thinking when its citizens happen to become slave of emotions aroused by propaganda was not merely a sociological analysis; it was first and foremost a logical thesis which could account for an essential feature of that concrete human activity which is reflective thinking - that is, the fact that the latter was a social activity that could be hampered and distorted by an uncontrolled emotional outburst of energies. More precisely, Dewey's argument was not intended to prove that emotion could actually replace thought; rather the contrary, it aimed at showing that, in certain occasions, propaganda could be strong enough to modify the logical endowment of a people by perverting the relation between thought and emotion. In times of war, Dewey remarked, emotion worked not by inhibiting thought in general, but, more subtly, by fostering "only those ideas which support and reinforce their own operation"; in doing so, it ended by producing "intellectual structures which effectively mask from view whatever trouble action were it recognized" (MW 10: 217).

In Dewey's eyes, the main effect of propaganda had been that of making most of the Americans intellectually blind, as a consequence of which they had lost their capacity to undertake inquiries. They continued to make use of general ideas and theories, but instead of using them in a logical way, they used them ideologically. As Dewey remarked, men always need a justification for what they are doing: "[m]en are profoundly moral even in their immoralities"; they cannot act without a moral justification of their decisions (MW 10: 217). The name that Dewey gave to this process of justification was 'idealization': through idealization, he remarked, people found a way to justify their beliefs without having to submit the latter to a process of rational evaluation. ${ }^{3}$ The 'logic' of idealization acted by severing the relations that hold together means and ends: ends and values were estimated more than specific purposes; "the nurture of personal motives" was privileged over "the creation of social agencies and environments" (MW 10: 262). Dewey seemed here to suggest that idealization was a sort of negative counterpart of rational investigation, characterized by its own distinctive logic, whose aim was precisely to undermine the very possibility of an intelligent treatment of social problems.

At that stage, Dewey did not use 'public' as a technical term; however, one promising way to clarify the difference between idealization and controlled inquiry in social affairs would be to say that the latter generates the public, while the former generates the masses. While the rise of the public originates from the conscious perception of the public consequences of a certain act, the rise of the masses in politics is a direct effect of the increasing complexity of social life, of the enormous quantity of energies released by dramatic events of contemporary life such as the First World War. Consequently, from a theoretical point of view, it can be said that the genesis of the public depends on the capacity of a society to prevent its people to become a mass. As is well known, a complete theory of the public was formulated by Dewey only in The Public and its Problems (1927), as an answer to the problems raised by Lippman. Almost nothing of this sort could be found in the texts that Dewey wrote in the war years. However, in these texts he did a preliminary work aimed at discovering what may be called the conditions of 'perturbation' of public reason. Such a preliminary work - which was mainly negative, since it was directed to highlighting the 'pathology' of public - was very likely the most 
difficult part of the project. Indeed, it compelled Dewey to go against the grain of his philosophy, focusing not on the positive, reconstructive function of thought, but rather on its intrinsic powerlessness.

\section{Dewey in China: Managing Cultural Differences}

It should be evident from what has been said until now that when the First World War eventually came to an end, Dewey's philosophy was dramatically different not only from the representation that Bourne had given of it two years before in the Twilight of Idols, but also from the shape that it had before the outbreak of the war. It was now richer, more concrete, less abstract and less schematic. It was more attentive to the social conditioning of thought as well as to the possible relativistic implications of such conditioning. It was undoubtedly less optimistic: on the one hand, the progressive refinement of the logical analysis had led Dewey to acknowledge the limits of the activity of thinking as well as the consequent problems that the latter pose to the theory and practice of education; on the other hand, the irrational forces released by the war, in internal as well as in international affairs, made him aware that the process of rational reconstruction of society was much more difficult and troublesome than he had previously realized. Finally, it was more 'prometheic' and more ambitious: if the assessment of the difficulties in which thinking is involved dispels easy optimism, it also stimulates human activity to tackle social problems with a renewed confidence in the capacity of the intellectual tools to account for the complexity of reality.

So, when Dewey finally arrived in China after a brief and far less productive stay in Japan, he had behind himself a concrete attempt - which had been lasting for a period of almost five years - to understand the complexity of social reality in all its many forms. Thanks to that preliminary work, he was lucidly aware - probably more aware than any other American philosopher of his time - that a great part of what was going on in contemporary societies was influenced by philosophies of life. His sojourn in China gave him the opportunity to put his theoretical assumptions to a far more trying test. ${ }^{4}$ Indeed, the object to be analyzed and understood was not simply a society completely different from America and Europe, but a world that was engaged in a ground-shaking revolution.

Dewey and his wife, Alice, arrived in China on May, 1st, 1919, three days before the outbreak of the Fourth May Movement. Their first impression of China was registered by Alice in a letter to her children, dated May, 3. Coming to China from Japan, Alice wrote, she had experienced a feeling of freedom and liberation from a world in which social life was completely controlled and regulated by fixed rules of behavior (Letter, A. Chipman Dewey to her Children, May 3, 1919). Dewey agreed with his wife's remark. In an article published few months later, he noticed that, even though it was a "three days easy journey from Japan to China," "[i]t is doubtful whether anywhere in the world another journey of the same length brings with it such a complete change of political temper and belief" (MW 11: 174). In a letter to his children, dated May, 9, he stressed the differences between the two nations by saying that while Japan was "baffling and tantalizing," China was "overpowering" (Letter, J. Dewey to his Children, May 9, 1919). In another letter he wrote that the feeling that he was "going to see more of the dangerous side of life" was more than welcomed (Letter, J. Dewey to his Children, May 3, 1919). Dewey could not suffer the "feeling of weakness current in Japan about Japan itself": he disliked the sense of doubleness that characterized Japanese society, the distinction drawn between internal 
and external, the desire to preserve the society unmodified (MW 11: 176; see also Letter, J. Dewey to A. Barnes, September 15, 1919). He needed something more concrete and genuine; he needed to get in touch with a living and troublesome reality.

No surprise therefore that Dewey was truly impressed and somehow excited by the Chinese situation. The obstacles that Chinese had to overcome were momentous: indeed, the problem at stake was not simply the modernization of China, but the preservation of its very existence against Japanese interference. At the Paris Peace Conference it had been decided that the German concessions in China should be transferred to Japan instead of being reverted to Chinese sovereignty. In doing so, the Western powers - with the remarkable exception of the United States - were implicitly supporting Japan's imperialist politics in China, thus hindering the formation of a Chinese national state. The consequence of that decision was a mass protest - the so-called Fourth May Movement which began with a student demonstration against the Chinese government, criticized for accepting the decision of the Western powers to give the Shandong province to Japan. In the very same letter in which he highlighted the differences between China and Japan, Dewey told his children about his views on what was going on in the country. He wrote:

[t]he other day the Peking univ students started a parade in protest of the Paris Peace Conference action in turning the German interests in China over to the Japanese. Being interfered with by the police they got more unruly and beat up the Chinese minister to Japan who negotiated the treaties that sold China out, he having been bribed; they burned the house where he was staying, and he went to the hospital, in fact was reported dead. Well, in one sense this was a kind of Halloween students spree with a somewhat serious political purpose attached. In another sense, it may be - tho probably not - the beginning of an important active political movement, out of which anything may grow. (J. Dewey to his Children, May 9, 1919)

Over time Dewey become more and more enthusiastic about the possibility of a revolution that could transform Chinese society. He sided with the students; he supported the boycott of the merchants; he felt that what was happening was a raising of public opinion. It is easy to see why Dewey was so excited by the opportunity to get involved in the Fourth May Movement: pure chance had put him at the very center of an epochmaking event; he was not simply in the position of observing and commenting on facts; he was part of them, and he could legitimately hope to be a factor influencing them. What was going on in China was nothing less than "the transformation of the mind of China": "the realm problem of the Pacific," Dewey observed, "is the problem of transformation of the mind of China, of the capacity of the oldest and most complicated civilization of the globe to remake itself into the new forms required by the impact of immense alien forces" (MW 11: 206). Dewey realized that the Fourth May Movement was a major occasion to test his idea of social philosophy, and, at the same time, to actively intervene in the course of events. As he himself remarked in one of his earlier articles on China, "[t]o the eye of the mind [China] presents the most enthralling drama now anywhere enacting" (MW 11: 214; see also MW 12: 41, and MW 13: 94).

At the same time, however, Dewey clearly perceived that China was different from almost everything that he had had experience of in his life. In one occasion, Dewey spoke of "[t]he baffling and 'mysterious' character of China to the West" (MW 11: 209). Even time seemed to run differently in China: "the foreigner interpreter," he wrote in a sort of autobiographical mood, "comes to the scene with a mind adapted to the quick tempo of the West," but then she will soon realize that she is not "used to history enacted on the 
scale of that of China" (MW 11: 205). China has a history of four thousand years, Dewey remarked, so it is impossible that it could find "new courses" of action in a short span of time. The process of absorption and appropriation of Western knowledge needed much time and efforts to be completed. The main difficulty for a Westerner was precisely due to the fact that China was an evolving civilization which was not willing to adopt "western external methods for immediate practical ends": as Dewey observed, "the Chinese genius does not lie in that direction" (MW 11: 207). But this meant that even those concepts that lied at the basis of Western political and social philosophy - as, for instance, the concept of State to which Dewey had devoted considerable attention in his Reconstruction of Philosophy - were not reliable tools for understanding the Chinese situation: "[n]either our political science nor our history," he bitterly remarked, "supplies any system of classification for understanding the most characteristic phenomena of Chinese institutions" (MW 11: 210).

As usual in Dewey, the difficulty to cope with a different reality turned out to be a logical problem - that of the reliability of the Western categories of thought. He did not take much time to realize that his conceptual framework did not fit very well to the Chinese situation, and that in order to properly understand the latter he had to strip off most of his habits of thought. ${ }^{5}$ Accordingly, he adopted the attitude of a cultural anthropologist. Keeping faithful to his instrumentalist approach, however, he tried not only and not simply to describe the main differences between the two cultures; he also attempted to explain the reasons why Chinese mentality had taken its characteristic shape.

In particular, Dewey was deeply surprised by a specific trait of Chinese mentality. "The Chinese," he remarked, "talk more easily than they act - especially in politics [...]. One of the defects upon which they dwell is the love of finding substitutes for positive action, of avoiding entering upon a course of action which might be irrevocable." (MW 11: 176). Their motto could be formulated as follows: "If things are fairly well off, then let well enough alone. If they are evil, endure them rather than run the risk of making them worse by interference." (MW 12: 54). In the article "As the Chinese think," originally published in 1922 and then reprinted in Characters and Events with the significant title (chosen by Joseph Ratner and approved by Dewey) "The Chinese Philosophy of Life," Dewey rhetorically asked: "Why are the Chinese so unperturbed [...] Is their attitude one of callous indifference, of stupid ignorance?" And then he added: "Is her [of China] course stupid inertia, a dull obstinate clinging to the old just because it is old? Or does it show something more profound, a wise, even if largely unconscious, aversion to admitting forces that are hostile to the whole spirit of her civilization." (MW 13: 221). In a letter to Barnes, he noticed that there were many things in China that made him believe that the "future [was] with China"; nonetheless, the Chinese did not seem interested in "bring [ing] in that future." "The puzzle of their contrasting strong and weak sides," he wrote, "is one of the most fascinating things I[']ve ever experienced, and keeps one always on the alert to see what is coming next [...]. It is a fascinating game to watch, but hard to repress one desire for a [little] more $\mathrm{d}[\mathrm{i}]$ rect western energy to tackle things before they get to the top[p]ling over point." (Letter, J. Dewey to A. Barnes, September 15, 1919; see also Wang 2007: 75ff.).

42 As should be evident, the Chinese tendency towards inaction posed a powerful challenge to Dewey's thought: one of the pillars of his philosophy was the idea that inquiry has a temporal structure, that it is an intermediate stage of experience, and that an intelligent action is that which control the course of the events by assessing the means to achieve a 
certain end. Now, Dewey found himself confronted with a culture that was greatly suspicious of any active intervention in the course of events, that did not praise at all private initiative and personal responsibility, that was not confident in the power of intelligence. It seemed that, in China, the rational assessment of successful lines of behavior was actually replaced with a sort of passive attitude suggesting that the only wise thing to do was to wait for the unfolding of the events. In addition, Chinese culture did not believe that reflection could yield positive results in the field of politics - at least, if politics is conceived of as centering on the notion of Government. Since in those years Dewey was struggling to develop a consistent social philosophy, the empirical fact of a people utterly opposed to the very idea of social reform was something theoretically disturbing and problematic.

In other words, it seemed that Chinese civilization had developed a conception of reason which was at odds with Dewey's instrumentalism. The difficulty of the problem was enhanced by the fact that Dewey could not resort to any version of the idea of primitive mind in order to account for the Chinese 'logical difference. ${ }^{6}$ Indeed, his deep respect for the Chinese civilization did not allow him to think of it as undeveloped or less developed than the European culture: "no one who knows the Chinese," he wrote, "can believe that the difficulty is intellectual, that the people have not the mental gifts required in successful organization" (MW 12: 51). He often spoke of China as "the oldest and most complicated civilization of the globe"; it was clear to him that Chinese achievements in the fields of art and philosophy were not inferior to those reached by America or any other country in the world (MW 11: 206; see also MW 13: 93). At the very same time, Dewey did not believe that such a difference could be explained by postulating an alleged essential character that somehow marked all the products of Chinese civilization as different from those of the other cultures. He was never fascinated by that kind of metaphysical explanations that Oswald Spengler made so popular in his Decline of the West.

Dewey argued therefore that the Chinese civilization was the outcome of particular choices taken in the past - he significantly devoted great attention to the teachings of Laotze and Confucius; even in the Lectures in China there is evidence of that interest (Dewey 2015: I) - in order to cope with problems that were specific to the Chinese situation. As he wrote in "Chinese National Sentiment," referring to the traditional Western way of dealing with political questions, Europeans and Americans tend to take the European development "as a necessary standard of normal political evolution": "[w]e have made ourselves believe that all development from savagery to civilization must follow a like course and pass through similar stage" (MW 11: 215). Dewey was well aware that such an attitude was not only immodest and unjustified, but also harmful in that it prevented the understanding of the history of China as well as of its future course. The starting point of every possible analysis should be, therefore, the recognition that China had its own line of development, and that the latter was the only legitimate criterion for evaluating and predicting the behavior of the Chinese people. Consequently, he suggested that Chinese civilization should be interpreted "only in terms of the institutions and ideas which have been worked out in its own historical evolution" (MW 11: 216). "We can get the key to mental operations," Dewey remarked, "only by studying social antecedents and environment [...]. We have to understand beliefs and traditions to understand acts, and we have to understand historic institutions to understand beliefs." (MW 11: 210). strong continuity with his broad instrumentalist account of theories and philosophies of 
life since it relied on the assumption that the latter should be treated as essential elements of social reality. ${ }^{7}$ What is interesting in this case is that the nature and size of the differences between Chinese and Western civilizations led him to broaden the scope of his analysis to include geographical and economical considerations, and, in doing so, to revise and improve his account of the ideological function of ideas. Both in German Philosophy and Politics and in "On Understanding the Mind of Germany" Dewey had focused his attention on the problem of the justification of a line of conduct which, even though it was perceived as stemming from a body of beliefs (a mentality) different from that of the other Western countries, could be easily accommodated within a broader conceptual framework. In the end, Germans' activities were firstly directed toward achieving national unity, and then toward fostering the economic, social and military progress of Germany. These goal could hardly be said to be idiosyncratic because, in different degrees and in different ways, they were shared by all the European powers.

Dewey's description of the differences between the various national philosophies of life revolved around the metaphor of a plurality of languages, each of which represented the way in which a nation expressed "its own moral grounds in the terms which its history [had] made familiar and congenial" (MW 10: 218). In the case of China that approach did not seem very promising. On the one hand, the traditional seclusion of China was a wellknown fact - actually, it was the problem at stake - so that no real explanatory advantage could be gained by simply re-stating it. On the other hand, the 'Chinese difference' was so great that it was not possible to presuppose a shared set of beliefs or values that could provide a sort of general horizon of interpretation, in the light of which the various national histories could be understood and compared. The problem was precisely that such a horizon did not seem to exist - or, at least, it did not seem easy to discover it.

Consequently, it was not enough to appeal to the national history of China to account for the specific traits of Chinese mentality. Dewey realized that historical reconstruction did not have enough explanatory power, but had to be backed and supported by considerations of other kind. A much more radical approach was needed. In order to account for the 'Chinese difference' - the fact that Chinese did not seem to conceive of rationality in instrumentalist terms, as the search for the means by which to control the future course of events (or at least that they were not willing to adopt it as a method to solve their own problems) - he had to take a step further towards the elaboration of a theory of logic that could highlight the concrete, material factors on which the activity of thinking depends.

Dewey argued that the key to solve this puzzle was to acknowledge the full complexity of the context in which philosophies of life had originated as well as the problems that they were asked to face. He reasoned as follows. Despite all the differences in their national histories, Western countries are very similar in their environmental conditions. To put it rather simply: in the European countries and in America human beings have enough room to live together without hurting each other. The environmental conditions promote the development of personal initiative, and foster the adoption of an experimental attitude towards social problems. On the contrary, China presents a completely different scenario. It should not be overlooked, Dewey remarked, that its "extraordinary and longcontinued density of populations" is not simply a brute geographical and demographic fact; it is first and foremost an important structural factor whose effects had an enormous cultural impact (MW 12: 53). Historically, that situation of overpopulation had been the background condition that any Chinese attempt to formulate a new course of action had 
to take into account. Consequently, Dewey concluded, it is not particularly strange that the philosophy of life resulting from a confrontation with an environment so different from the one with which Europeans and Americans are acquainted is marked by specific and distinctive traits that have no comparable equivalents in any other country in the world.

Dewey's analysis is extremely sophisticated on this point. Thanks to his previous reflections on the social effects of propaganda, he was not uncomfortable with the idea that the activity of thinking could be conditioned by the concrete social circumstances in which the agent happens to find himself. He therefore used some of the principles lying at the basis of the notion of "psychology of crowd" to account for the diffidence of the Chinese towards initiative and experimentation. It is worth remarking, indeed, that one of the problems that the psychology of crowd was meant to solve was the irrational behavior of people when in large numbers, their incapacity to adopt a rational and reflective attitude on social matters when participating in a strike or manifestation. In the case of China, Dewey noticed, the situation was even more complicated because that condition was not an episodic event, but a standard fact of associated living. As he wrote, the psychologists who invented the mob-psychology "have not inquired as to the effect upon the mind of constant living in close contact with large numbers, of continual living in a crowd" (MW 12: 53).

It was on the basis of these assumptions that Dewey could eventually explain away the 'Chinese difference.' He moved from the assumption that any course of action human beings undertake - and logical investigation should be conceived of as a particular way of behaving in presence of other people - is dependent upon the environment with which they have to cope. Now, because of overpopulation in China there was no possibility of "solitude and loneliness": every act was a public act, every behavior was subjected to social approval or disapproval. There was "no room to stir about, no relief from the unremitting surveillance of their fellows" (MW 12: 53). Every person was constantly judged by the other persons who had a direct interest in the consequences of his activities: Chinese acquired "the fear that if one strand is touched, the whole will unravel," and accordingly they came to believe that "the safe thing [was] to leave things alone" (MW 12: 54). Consequently, the virtue of free and responsible initiative was quite naturally replaced by the attention to the "face," to public reputation, to the opinion of the others. "Imagine all elbow-room done away with, imagine millions of men living day by day, year by year, in the presence of the same persons (a very close presence at that)," Dewey remarked; if you could imagine that condition, "new light may be shed upon the conservatism of the Chinese people" (MW 12: 53).

Conservatism was then the source of the Chinese distrust in the power of reason to control and redirect the course of events. But Dewey never tired of stressing that Chinese conservatism was substantially different from the Western one. Chinese conservatism hinged upon the idea of the superiority of nature over man, the "laissez-faire reverence for nature," the doctrine that the world is not at our disposal (MW 13: 222). To clarify this point and to better highlight the differences between the Chinese and the Western form of conservatism, Dewey used the example of the belief in Feng-shui - that is, the belief in the existence of "mystical influences connected with the land" (MW 13: 224). That belief, which was an essential part of the Chinese philosophy of life as codified in the teachings of Laotze and Confucius, played a major role in obstructing and retarding the introduction of new industrial forces in China. From a Western perspective, the belief in 
Feng-shui was a cultural force opposing to the industrial forces aiming at the modernization and rationalization of China. It impeded the economic and political development of the country, its transformation in a modern nation with a strong central government and an economy based on industry and free market. However, in the broader context of the Chinese civilization that belief acquired a much more positive meaning: indeed, it represented an appeal to the conservation of natural forces, "a remarkable exhibition of piety toward nature," a warning against the risks of an uncontrolled exploitation of natural resources. If that belief were rationalized, Dewey remarked, "one would see in it a belief that the land and its energies belong to the whole succession of human beings, past generations and future" (MW 13: 224).

51 Against the Western emphasis on creativity and initiative, regardless of any possible future consequences on the environment, the Chinese civilization advanced a different conception of life and nature, much more respectful of the soil and its fertility. The ultimate reason of the 'Chinese difference' relied precisely here, on the fact that, traditionally, China was "agrarian, agricultural"; and the success of the teachings of Laotze should be traced back to their capacity to express "something congenial to Chinese temperament and habits of life." Among all the people, he wrote, Chinese were the only ones who succeeded in not exhausthing their soil: "the Chinese have gone on tilling, tilling, tilling, even, as in north China, against great odds; and their soil is still productive, as productive, probably, as ever it was" (MW 13: 222).

Consequently, Dewey held conservatism to be a positive value of Chinese civilization - in a twofold sense. On the one hand, it was positive in a functional, articulative sense: conservatism was an apt response to the particular environmental conditions with which Chinese had been confronted for thousands of years. It stemmed from the need to preserve what was most precious for them - the resources of nature. With a remarkable image, Dewey said that "[t]heir minds are as steeped in contact with natural processes as their bodies are apt for agricultural work" (MW 13: 222). It was natural for them to "wait for the fruition of slow natural processes," to give nature the "time to do her work" (MW 13: 223, and MW 13: 222). And, similarly, it was natural for them to believe that "[t]he workings of nature will in time bring to naught the artificial fussings and fumings of man," their motto being "[c]onquering by yielding" (MW 13: 222). On the other hand, it was positive in the moral sense of the term: indeed, it represented a different set of values, contrary and alternative to the Western worldview, and nonetheless worthy of preserving. As Dewey explicitly remarked, "the Chinese philosophy of life embodies a profoundly valuable contribution to human culture and one of which a hurried, impatient, over-busied and anxious West is infinitely in need" (MW 13: 223).

53 As should be evident, the overall tone of Dewey's philosophy as well as its specific doctrines were substantially different from the ones formulated in his previous writings: his attempt to come to terms with the 'Chinese difference' prompted him to radicalize his thought in a direction that led him to formulate in a more inclusive and holistic way the relation between nature and culture. In order to account for Chinese conservatism he had to admit that theories and ideas - the realm to which philosophies of life belong - were sensitive to the natural, environmental conditions in which they originated, such conditions being a major component of what a philosophy of life had to articulate. In doing so, he came to see that cultural choices were responsive to the 'natural' traits of the situation, while, at the very same time, the latter found their proper realization in the civilization whose development and evolution they directly supported or hindered: "[ $t]$ he 
teachings of Laotze," he remarked, "spring from the depths of Chinese life and in turn they have influenced that life" (MW 13: 223). A civilization thus became a self-included whole - a sort of cultural organism - in which cultural aspects (philosophies of life) and natural aspects (environmental conditions) were so closely interwoven that they were impossible to disentangle.

The realization of the intertwining of nature and culture was consistent with Dewey's overall philosophical project, and in particular with the philosophical anthropology that he sketched in the series of lectures published in 1922 as Human Nature and Conduct, based on the notions of natural, unarticulated instincts and culturally mediated habits. ${ }^{8}$ It did not represent, therefore, a theoretical novelty: it was more a matter of different emphasis than of different meaning. However, the introduction of this new conceptual tool within the context of Dewey's thought had some important bearing upon his social philosophy. First of all, it paved the way for a naturalized, anti-reductionist account of the notion of philosophy of life, and, more in general, of the ideal dimension of human behavior: in his articles on China, Dewey was willing to treat philosophies of life as natural events that had to be discussed and dealt with in a purely naturalistic and experimental way, without denying their autonomy as ideological products. It also implied that a social philosophy which aimed to provide an account of social reality should become more and more empirical and concrete, more terrestrial and attentive to the material background of theories. As a consequence, the notion of philosophy of life became a richer and more powerful tool of analysis, which could enlarge the explanatory power of his pragmatist social philosophy grounded on the notion of ideological articulation.

Two were the main theoretical consequences that followed from such a change of perspective. The first one was the idea of the 'humility of thought,' which could be read as a sort of radicalization of the notion of 'limits of thought.' We saw above that Dewey's analysis of the harmful effect of propaganda on American society was intended to highlight the 'pathologies' that could affect thought. In that case, the reconstructive activity of thinking was conceived of as a value to preserve against the menace of irrational forces at work in the contemporary world. To put it roughly, Dewey believed that the activity of thinking was intrinsically good, and the preservation of its very possibility was an end to attain. Dewey's reflections on the 'Chinese difference' partially modified this view, which was too simplistic. It is not that Dewey rejected the instrumentalist tenet that rationality is the means-ends evaluation, with the aim of controlling a future course of action. This would be probably a too strong statement, even though it is possible to find some quotations that support such interpretation. ${ }^{9}$ Rather, he became suspicious of the too naïve belief in the neutrality and unproblematic character of the recourse to thinking activity. In China, he remarked, "[i]nnovation, experimentation, get automatically discouraged, not from lack of intelligence, but because intelligence is too keenly aware of the mistakes that may result, the trouble that may arise" (MW 12: 58). The philosophical contribution of the Chinese civilization amounted precisely to this - to call attention to an aspect which had gone completely neglected in Western culture. That is, that in certain particular situations even our most precious and successful tools could turn into a menace for ourselves and other people.

The second theoretical achievement was the idea of the cultural contingency of thought. In his previous writings Dewey had always treated logical activity as a sort of universal constant, even in those cases in which he was concerned with its social pathologies. That he was strongly committed to the belief in the 'universal validity' of thought (as codified 
by Western civilization) is shown by the fact that when he first tried to advance some proposals on how to solve the problems of China, he relied on the assumption that Western method and knowledge could provide a reliable means to reach the ends that Chinese wanted to achieve, even though that assumption led him to completely antipragmatist conclusions - such as, for instance, the view that means could be given before and independently from the end that they were supposed to bring about, and the end could be, in its turn, determined without taking into account the means available to the agents. So, for instance, in the article "What Holds China Back," published in May 1920, he argued that the only way to change how Chinese thought, acted and felt was not "by expostulation, exhortation and preaching." That would have amounted to a complete misunderstanding of how deeply was that mentality rooted in the material conditions with which Chinese civilization had to cope, and of how ingrained was it in the habits of behavior of the Chinese people. Rather, he suggested that what was needed was a "change of conditions, an alteration of environment," and that "an introduction of modern industrial methods" was the only thing that could "profoundly affect the environment" (MW 12: 59). Now, from a certain point of view, Dewey's proposal was genuinely pragmatist since it acknowledged that the ideal dimension of human activity could not be severed from the material in which it happens to be embodied. As Dewey wrote in the Lectures in China, "[i]deas, theories are originally products, causes of non-intellectual forces" (Dewey 2015: I.3). However, by recommending the application of Western tools to solve Chinese problems, he implicitly admitted that, no matter what was the problem, it could be handled by Western means. But this was not a conclusion that Dewey could accept without reservation and embarrassment.

One would be willing to say that this tension within Dewey's philosophy was due to the fact that the different strands of his thinking did not develop in parallel: at the time he wrote "What Holds China Back," Dewey was well aware that philosophies of life had to be treated as natural events, but he did not succeeded in drawing all the possible conclusions from that thesis. As a consequence, his logical account of thinking was not consistent with his naturalism. Two years later, when he wrote "As the Chinese Think," his position was much more consistent. In the context of a discussion of Chinese conservatism, Dewey drew a comparison between the Western and the Chinese mentality. He wrote: "[w]hile western peoples have attacked, exploited and in the end wasted the soil, they [the Chinese] have conserved it." And then he concluded: "[t]he results are engraved upon both Chinese and western psychologies" (MW 13: 223). No pride of place was given to Western civilization. The analysis contained in that article shows that he had now realized that the logical activity of thinking, Western technology, the whole body of Western knowledge, were all part of a civilization which was not less grounded on a particular philosophy of life than the Chinese one.

Dewey's attempt to come to terms with the 'Chinese difference' resulted therefore in a philosophical position which was radically pluralist, anti-foundationalist, and which nonetheless did never indulge in the quietism to which relativism inevitably leads. His eye was now trained to perceive the different layers that made up social reality. His confrontation with the Chinese civilization reminded him of something which he had to know very well, that is, that much of what we are ready to assume to be natural is, in reality, second nature. 


\section{Conclusion}

59

After a twenty-six month stay in China, Dewey eventually went back to the United States in October 1921. He returned to his previous job; he was again a professor of philosophy after two years in which he had "no philosophical reading at all" (Letter, J. Dewey to F. C. S. Schiller, July 18,1922$)$. Occasionally, he wrote some articles on China, but his attention was captured by other concerns. The remaining part of the third decade of the century was devoted to developing a naturalistic metaphysics: the problem of accounting for the relation between ideal and real was replaced by the problem of understanding the relation between nature and meaning, between naturalism and humanism. The aim of a future research will be to determine how much of the theoretical achievements that Dewey had reached in the period 1915-1921 passed into the new phase of his philosophy, and too evaluate if something that did not receive adequate recognition in this new phase could be preserved and revitalized in the contemporary philosophical debate.

\section{BIBLIOGRAPHY}

BOURNE R., (1917), “The Twilight of Idols,” Seven Arts, Vol. II, October 1917, reprinted in J. E. Tiles, ed., John Dewey. Critical Assessments, Vol. II. Political Theory and Social Practice, London, Routledge 1992, 199-208.

DEWEY J., (1897), "The Significance of the Problem of Knowledge," in The Early Works of J. Dewey, 1882-1898, Vol.5 (1895-1898), J. A. Boydston, ed., Carbondale, Southern Illinois University Press, 2008, 4-24.

DEWEY J., (1902), “Interpretation of Savage Mind," in The Middle Works of J. Dewey, 1899-1924, Vol. 2 (1902-1903), J. A. Boydston, ed., Carbondale, Southern Illinois University Press, 2008, 39-52.

DEWEY J., (1903), Studies in Logical Theory, in The Middle Works of J. Dewey, 1899-1924, Vol. 2

(1902-1903), J. A. Boydston, ed., Carbondale, Southern Illinois University Press, 2008, 293-378.

DEWEY J., (1908), Ethics, in The Middle Works of J. Dewey, 1899-1924, Vol. 5 (1908), J. A. Boydston, ed., Carbondale, Southern Illinois University Press, 2008.

DEWEY J., (1910), How We Think, in The Middle Works of J. Dewey, 1899-1924, Vol. 6 (1910-11), J. A.

Boydston, ed., Carbondale, Southern Illinois University Press, 2008, 177-355.

DEWEY J., (1915), German Philosophy and Politics, in The Middle Works of J. Dewey, 1899-1924, Vol. 8

(1915), J. A. Boydston, ed., Carbondale, Southern Illinois University Press, 2008, 135-204.

DEWEY J., (1916), Democracy and Education, in The Middle Works of J. Dewey, 1899-1924, Vol. 9 (1916), J.

A. Boydston, ed., Carbondale, Southern Illinois University Press, 2008.

DEWEY J., (1916a), “On Understanding the Mind of Germany," in The Middle Works of J. Dewey, 1899-1924, Vol. 10 (1916-17), J. A. Boydston, ed., Carbondale, Southern Illinois University Press, 2008, 216-233.

European Journal of Pragmatism and American Philosophy, VII-2 | 2015 
DEWEY J., (1917), “Conscience and Compulsion," in The Middle Works of J. Dewey, 1899-1924, Vol. 10 (1916-17), J. A. Boydston, ed., Carbondale, Southern Illinois University Press, 2008, 260-264.

DEWEY J., (1919a), "On the Two Sides of the Eastern Sea," in The Middle Works of J. Dewey, 1899-1924, Vol. 11 (1918-19), J. A. Boydston, ed., Carbondale, Southern Illinois University Press, 2008, 174-179.

DEWEY J., (1919b), “Transforming the Mind of China,” in The Middle Works of J. Dewey, 1899-1924, Vol. 11 (1918-19), J. A. Boydston, ed., Carbondale, Southern Illinois University Press, 2008, 205-214.

DEWEY J., (1919c), “Chinese National Sentiment," in The Middle Works of J. Dewey, 1899-1924, Vol. 11 (1918-19), J. A. Boydston, ed., Carbondale, Southern Illinois University Press, 2008, 215-227.

DEWEY J., (1920), Reconstruction of Philosophy, in The Middle Works of J. Dewey, 1899-1924, Vol. 12 (1920) ,J. A. Boydston, ed., Carbondale, Southern Illinois University Press, 2008, 77-201.

DEWEY J., (1920a), “What Holds China Back," in The Middle Works of J. Dewey, 1899-1924, Vol. 12 (1920) ,J. A. Boydston, ed., Carbondale, Southern Illinois University Press, 2008, 51-59.

DEWEY J., (1922), Human Nature and Conduct, in The Middle Works of J. Dewey, 1899-1924, Vol. 14 (1922), J. A. Boydston, ed., Carbondale, Southern Illinois University Press, 2008.

DEWEY J., (1922a), “As the Chinese think," in The Middle Works of J. Dewey, 1899-1924, Vol. 13 (1921-1922), J. A. Boydston, ed., Carbondale, Southern Illinois University Press, 2008, 217-227. DEWEY J., (1973), Lectures in China 1919-1920, Honolulu, The University Press of Hawaii. DEWEY J., (2015), “Lectures in Social and Political Philosophy," The European Journal of Pragmatism and American Philosophy 7 (2), 7-44.

Letter, A. Chipman Dewey to her Children, May 3, 1919, The Correspondence of John Dewey, Volume 2, 1918-1939, Electronic Edition, L. Hickman, ed., Charlottesville, Intelex.

Letter, J. Dewey to his Children, May 3, 1919, The Correspondence of John Dewey, Volume 2, 1918-1939, Electronic Edition, L. Hickman, ed., Charlottesville, Intelex.

Letter, J. Dewey to his Children, May 9, 1919, The Correspondence of John Dewey, Volume 2, 1918-1939, Electronic Edition, L. Hickman, ed., Charlottesville, Intelex.

Letter, J. Dewey to A. Barnes, September 15, 1919, The Correspondence of John Dewey, Volume 2, 1918-1939, Electronic Edition, L. Hickman, ed., Charlottesville, Intelex.

Letter, J. Dewey to F. C. S. Schiller, July 18, 1922, The Correspondence of John Dewey, Volume 2, 1918-1939, Electronic Edition, L. Hickman, ed., Charlottesville, Intelex.

FALLACE T. D., (2011), Dewey and the Dilemma of Race. An Intellectual History, 1895-1922, New York, Teacher College Press.

FREGA R., (2015), “John Dewey's Social Philosophy: A Restatement,” The European Journal of Pragmatism and American Philosophy 7 (2), 98-127.

GRAMSCI A., (1971), Selections from the Prison Notebooks, New York, International Publishers.

KOOPMAN C., (2010), “The History and Critique of Modernity: Dewey with Foucault against Weber," in P. Fairfield, ed., John Dewey and Continental Philosophy, Carbondale, Southern Illinois University Press, 194-218.

LIVINGSTON J., (2003), "War and the Intellectuals: Bourne, Dewey, and the Fate of Pragmatism," The Journal of the Gilded Age and Progressive Era 2 (4), 431-450.

MARTIN J., (2003), The Education of John Dewey: A Biography, New York, Columbia University Press. 
ROGERS M., (2009), The Undiscovered Dewey: Religion, Morality, and the Ethos of Democracy, New York, Columbia University Press.

SAITO N., (2011), "Becoming Cosmopolitan: On the Idea of a Japanese Response to American Philosophy," Transactions of the Charles Sanders Peirce Society 47 (4), 507-523.

SAITo N., (2012), “Is Thoreau More Cosmopolitan than Dewey?," The Pluralist 7 (3), 71-85.

STUHR J., (2015), Pragmatic Fashions. Pluralism, Democracy, Relativism, and the Absurd, Bloomington, Indiana University Press.

TORRES COLON G. \& C. HOBBS, (2015), “The Intertwining of Culture and Nature: Franz Boas, John Dewey, and Deweyan Strands of American Anthropology," Journal of the History of Ideas 76 (1), 139-162.

WANG CHING-SZE J., (2007), John Dewey in China. To Teach and to Learn, New York, State University of New York Press.

\section{NOTES}

1. The number of secondary literature about this subject is so extensive that it is impossible to give a comprehensive bibliography. Two very interesting approaches are however provided by Stuhr (2015, Chapter 7), and Livingston 2003.

2. Dewey's conception of modernity is an unexplored issue. To my knowledge, the only attempt to thematize this problem, which is fundamental to understanding Dewey's philosophy, is Koopman 2010.

3. From this point of view it is relevant what Dewey wrote in his article "Conscience and Compulsion" (1917): "One of my most depressing experiences in connection with this matter was the number of young men who when war was actually declared merely clumsily rolled their conscience out from under the imperative of 'Thou shalt not kill' till it settled under the imperative of 'Obey the law' although they still saw the situation exactly as they had seen it before" (MW 10: 263).

4. For a similar reading, even if more concerned with Dewey's political philosophy, see Wang (2007: 65ff). For a discussion of the philosophical significance of Dewey's visit in Japan, see Saito 2011 and 2012.

5. See, for instance, Letter, J. Dewey to H. W. Schneider, January 3, 1921; quoted in (Wang 2007: 75).

6. On this point, see Fallace 2011. In his book Dewey and the Dilemma of Race, Fallace has convincingly shown that by 1916 Dewey started criticizing the traditional evolutionary view (which he himself had previously adopted) according to which native and primitive societies should be conceived of as earlier and less developed stages of civilization that our "modern, civilized culture had moved beyond" (Fallace 2011: 3-4; see in particular MW 2: 39-52). Dewey came to realize that the relation between civilized cultures and 'primitive' ones could not be explained in terms of lower and higher levels of growth within a linear process of cultural development, but rather in terms of different realizations of a set of natural instincts which constitute our biological endowment.

7. In the article "As the Chinese think," Dewey did not hesitate to say that even the economic factors should be conceived of as subordinated to cultural factors. This was an explicit rejection of the Marxist thesis of the determinant character of the economy. Contrary to that tradition, which assumed that "the causes of all difficulties between nations [were] economic," he rebutted that "the friction generated by economic competition and conflict would not break out into the 
flames of war if atmospheric conditions were not favorable." And then he concluded by remarking that the origin of social conflict was intrinsically moral and intellectual: " $[t]$ he atmosphere that makes international troubles inflammable is the product of deep-seated misunderstandings that have their origin in different philosophies of life" (MW 13: 218).

8. On this point, see Torres Colon \& Hobbs 2015.

9. See, for instance, (MW 13: 221).

\section{ABSTRACTS}

This paper aims to investigate the transformations undergone by Dewey's philosophy in the period from 1916 to 1921. By analyzing three different problematic situations with which Dewey found himself confronted (German militarism; the effects of propaganda on American society; the experience of a two-year stay in China), the paper seeks to show the various lines of development at work in his thought. The thesis of the paper is that in the war and immediately post-war years Dewey was concerned with outlining a new account of the nature of theory which was preliminary to the formulation of his social philosophy. The paper presents Dewey's main philosophical achievements, with the aim of providing some background knowledge that could be useful to understanding that place and significance of the Lectures in China in the overall context of his thought.

\section{AUTHOR}

\section{ROBERTO GRONDA}

Università di Pisa

roberto1gronda[at]gmail.com 